\title{
IMPACT OF LAND CONFLICT ON AGRICULTURE PRODUCTION: A CASE STUDY OF THE ALAVANYOS AND NKONYAS OF GHANA
}

\author{
Emmanuel Abeku Essel, MSc, PhD student ${ }^{1}$ \\ School of Public Administration, Society and Governance, National University of Public Service
}

\begin{abstract}
Conflict largely is and has always been part of all human endeavours, however one particular area where conflict has created problems has been land conflict where tribes owing to their beliefs and cultures feel that lands they occupy has been a heritage property that had been handed down from generation. Land remains an important natural capital for every nation and individuals, and because of this, it is not unusual that there is land conflict across the world, especially in developing nations like Ghana where a huge population depends on agriculture for their livelihood. A case of a protracted land conflict in Ghana is between the people of Nkonya. and Alavanyo. The objective of this paper was to access the impact of land conflict between the Nkonyans and Alavanyos of Ghana on agriculture production. It also professes some recommendations. The paper was conducted as a desk study and the author relied mainly on secondary data.
\end{abstract}

Keywords: impact, land conflict, agricultural production

JEL code: Q15

\section{INTRODUCTION}

Agriculture remains one of the fundamental drivers of the Ghanaian economy as it is expected to grow at an average of $3.3 \%$ yearly until the end of 2018 and contributes $25 \%$ to the nation's Gross Domestic Product (GDP). According to the Food and Agriculture Organisation (FAO) (2016), food security and agriculture have an essential role to play in preventing conflicts and crises on the African continent, blunting their impacts and acting as engines for post-crisis recovery. The rate of urbanization and whether food production can keep pace with population growth have been an issue of concern and analysis dating back to the past couple of centuries since Malthus' days (Salih, 1995). Conflicts of land use has become the norm of the day as clans, chiefs and individuals claim lands for themselves without the recourse of what happens to the people who are using the land for farming purposes. Land conflicts between private developers and native rural communities over what constitutes native customary land have being a source of controversy in Ghana. A case in point is the Nkonya-Alavanyo conflict.

From the sociologists' point of view, conflict is defined as a social fact in which at least two or more parties are involved and whose origins and differences either in interests or in the social position of the parties (Imbusch, 1999). Niklas and Mikael (2005) described conflicts as a struggle or contest between

${ }^{1}$ Corresponding author: Ludovika Ter 2, 1083 Budapest, Hungary, emmanuel.abeku.essel@hallg.uni-nke.hu, abeabi@yahoo.com, +36204671537 
people with opposing needs, ideas, beliefs, values, or goals. According to Boulding (1963) conflict 'is a situation of competition in which the parties are aware of the incompatibility of potential future positions and in which each party wishes to occupy a position that is incompatible with the wishes of the other'. The Heidelberg Institute for International Conflict Research (HIIK, 2005) explains conflict as 'the clashing of interests (positional differences) on national values of some duration and magnitude between at least two parties (organised groups, states, groups of states, organisations) that are determined to pursue their interests and win their cases'. This definition establishes the fact that, conflict takes place between organised groups on national values within a period, depending on the intensity of their differences.

Wehrmann (2005) opines, 'land conflict is a social fact in which at least two parties are involved. The roots of which are different interests over the property rights to land: the right to use the land, to manage the land, to generate an income from the land, to exclude others from the land, to transfer it and the right to compensation for it'. He further added that, 'land conflict could be understood as a misuse, restriction or dispute over property rights to land'. There are four descriptions which according to him differentiates land conflict from all others conflicts. These are Boundary conflicts, Ownership conflicts linked to inheritance, Ownership conflicts due to legal pluralism and Ownership conflicts due to lack of land registration. At a microscopic analysis of the Alavanyo and Nkonya conflict one can identify some, if not all of the description given by Wehrmann as the cause for the conflict.

While Ghana has been so described as peaceful, it is evident that violence occurs from time to time involving various protagonists that may be ethnic, religious, economic or political. Attempts have been made by various agencies to establish a database of conflict zones and to design early warning systems to help pre-empt violence. Some parts of Ghana have been plagued with communal struggles, particularly land and chieftaincy related conflicts in the past two decades or more. Some of these conflicts easily engage the attention of the country as a whole and, in some cases, the international community. The ethnic conflicts between Nanumba-Kokomba, Nkonya-Alavanyo, Konkomba versus Gonja, Dagomba, Nanumba; Gonja versus Vagla wars as well as violent chieftaincy conflicts in Dagbon, Winneba and Gushiegu are examples. Economic violence (settler farmers versus host communities, pastoralists versus farmers), political violence and cultural violence that are more subtle are constantly threatening the peace. The study looks at the Impact of Land Conflict on Agriculture Production using the Alavanyos and Nkonyas of Ghana as a case study.

\section{THE ALAVANYO AND NKONYA CONFLICT}

Boucher, Landis and Clark (1987) argue that differences between ethnic groups have been a primary source of unrest in the world. Aapengnuo (2010) advances a contrasting view when he argues that ethnic differences have not been a driving force for conflict but rather, it is when their differences are used as 'barrier to advancement and opportunity' that conflict ensue. Ethnic conflict by extension to Bates (1982) refers to disagreements between 'rational agents over scarce resources'. While the basic resource under contention in the Nkonya-Alavanyo conflict is land and fought along ethnic lines. The size of the disputed land covers an area of 6,459.82 acres or 2,616.23 hectares, and is rich in timber, fertile for agrarian activities and alleged to have deposits of gold, mercury and clay (Gariba, 2015).

An Nkonya chronicle asserts that the Guans were the first settlers of their present day location, long before the coming of the Europeans in 1484. A claim Nana Okotor Kofi III argues is yet to be refuted (Nkonya Traditional Council, 2013). The Alavanyos according to Dzathor (1999) were fugitives who flew persecution from their original home in Saviefe through Akrofu to Soviet (near Kpando), to their present location. His version points that the Alavanyos, who were originally known as Bubulubu, which means 'someone or something big', were upon the request of Fia Tatse Koku, granted them residence in their current location by Kondodze of Nkonya Akloba on accounts of their friendship. Upon settling on the apportioned piece of land and realising that the place was not very 
attractive, their leader declared: 'miamo fii kpo; adabanyo' which means that 'let us venture into settling here; it might turn out to be successful'. It is worth mentioning that 'adabanyo' is what has been corrupted over the years to mean Alavanyo (Ohene, 2013). The attempt to resolve this conflict saw the various communities seeking assistance from the colonial authorities. Ultimately, it resulted in the designing of a map by a German Cartographer called Dr Hans Grunner in 1913. This came about because, Some allegation have also been directed towards the upshots from the sharing of the erstwhile German Colonies to Principal Allied and Associated Powers as specified in the Treaty of Versailles on 28 June 1919. According to Article 119 of the treaty, Germany was mandated to relinquish her right and titles over her overseas territories, including German Togoland paving the way for their repossessions (Kumado and Gyandoh, 2009). With time, the conflict took different shapes and tangents. While a number of the escalations have been triggered by land related issues, an outbreak in 1983 was largely out of a conflict between two individuals over the fetching of water. This quickly escalated into an Nkonya-Alavanyo affair with resultant loss of lives.

\section{LAND TENURE SYSTEM AND CONFLICTS IN GHANA}

Land, a natural resource and a necessary tool in human life is highly valued in all African societies and there are many rules and rituals concerning its use (Sarpong, 1974). Land is also of basic importance in the identity, integrity, solidarity and culture of any group of African people (Quarcopoome, 1992). In Ghana, as a rule, land is vested in the descent groups and families, but in centralized political societies like the Akans and Dagomba is not a society the stool/ skin lands, where land is entrusted to the king or chief who administers it on behalf of his people. According to Asabere (2004), in Ghana, 'chiefs' dominate the traditional land tenure system. Among the Ewes, however, stool lands do not exist as ultimate land ownership is vested in descent groups (Nukunya, 2003). The notion that land is communally owned was expressed in the statement that land is actually owned by the present living members of the society who inherited it from the ancestors and are expected to use it and pass it on to the next generation.

Lasterria-Cornhiel and Frais (2009) have categorized land tenure into private, communal, open access and state. Ghana has both traditional and statutory land tenure systems. The different types of land tenure and the land administration prevailing in Ghana today evolved over-time from the interplay of sociopolitical organization of various ethnic groups, clans and families, through trade, wars and incorporation. Gyasi (1994) identified lands acquired through leasing and sharecropping as the forms of land acquisition processes relating to the tenure systems among the Akans in Ghana.

\section{IMPACT OF LAND CONFLICT ON AGRICULTURE PRODUCTION}

Land conflict reduces agricultural productivity as identified by the government has in recent times realized the economic and political impacts of such conflict on the country's agricultural production capacity (Kairaba, 2002). Francis and Tomoya (2013) found that land conflict could reduce agricultural productivity on plots by $17 \%$. Unfortunately, this affects vulnerable groups like female-headed households and widows (Deininger and Castagnini, 2004). It could be added that vast land for agricultural production in the affected areas of the conflict lies fallow because people are afraid to go to the land to farm. Again, in all areas in Ghana where land conflict had erupted, agricultural production is affected because high intensity farming is reduced to low intensity farming. Further to that, the conflict within the two communities has become a menace as farmers in their agricultural production activities employ all manner of negative or aggressive conflict handling methods, leading to a reshaping of agricultural landscape of the areas. Not only that, in any conflict situation in any community, agricultural productive activities of the feuding parties are often reduced and the people of Nkonya and Alavanyo are no exception. This happens because time, energy, material and human resources are diverted into fighting. 
Land conflicts impose costs on economic production through two broad channels: aggressions and attacks leading to a situation where non-state armed actors pushes households to modify behaviour in spite of not facing violent shocks. In Ghana, women contribute 70 to $75 \%$ of the overall agricultural production, however owing to the conflict in the Alavanyo and Nkonya districts, the level of the percentage in agricultural productions have been low. The women are forced to flee for their lives due to the conflict. Again, contribution by women to agricultural development are being constrained by limited property rights to access and control over land (World Bank Group, 2008; Deininger, Goyal and Nagarajan, 2010; Vandana, 2010). Peters (2004) asserts that conflict over land intensifies when rural community increases their production level with the retrenched members seeking for more land to improve their food security and income level. With the declining soil fertility and population growth rate land tenure security need to be safeguarded in order to address the growing demand for food.

Although richly endowed with natural resources, Ghana remains comparatively underdeveloped, primarily because of protracted civil strife and poor economic management, (FAO, 2005). Ownership of large agricultural lands is not a common phenomenon to the natives of Alavanyo and Nkonya as most of them own small farms, often cultivating on arable lands about three hectares. Agriculture is and still is the foundation and the main source of economy for the natives of Alavanyo and Nkonya. Other major agriculture-related activities that are disrupted due to the land conflict were the transportation and credit services (including both government-run and private local service providers). Credit service providers, such as banks and microfinance institutions, left the conflict zone. Informal credit options, such as obtaining loans from other members of the community, were also limited given the urgent need by every individual to care foremost for his or her farm before providing additional funds as sources of credit for other community members. The liberties of the citizens are curtailed because they are forced to sleep under curfew and also increased in military or security spending to protect life and property.

\section{CONCLUSIONS AND RECOMMENDATIONS}

This paper looked at impact of land conflict on agricultural production. It explored the effect the land conflict in the Alavanyo and Nkonya area is having on agricultural production. The study revealed that land conflict with its impact on agricultural production in the study area was triggered by local factors and some weaknesses in government, which do not allow most people to defend their land rights or to purchase their personal land. The cases of land conflict in the district is getting high compared to the past years, the drivers to such rise in the conflict level are among others; greed which force people to initiate land grabbing, land inheritance system, lack of boundary, misinterpretation of customary laws and lack of understanding of the existing land laws and order, resources scarcity triggered by population increase, declining soil productivity, poverty and high rate of unemployment in the country. Land conflict have serious impacts on the lives of men and women especially if they are losers. Also, land conflict has a negative impact on the agricultural production which ranges from missing of planting seasons, leaving of land to lie idle, a fall in capital investment and eventually. There is also a decrease in production level and reduced income, which contributes to food insecurity of households, which is further extended to the community through promoting of illegal practices like stealing of unharvested crops.

To reduce incidences of land conflict at the local community and that of Alavanyo and Nkonya areas, especially, the government should first address the weaknesses in the economy and in the implementation of land laws and policies. The existing land laws and policies should be translated into the local languages and made available to the local communities to help them understand the laws in place. Traditional post-conflict policies should focus on reconstruction efforts, which are necessary to increase agricultural production in a short period of time. Policies should also create favourable conditions to reduce uncertainty. As a means of finding a lasting solution to land conflicts in the country, the government through the various Houses of Chiefs is encouraging the use of the law courts to solve most of the land conflicts 
because the citizenry are see the courts as a means to resolve their differences. Added to that, existing traditional and cultural systems are being encouraged and this is yielding positive results. A clear case in point was the Bimbilla land conflict, something that could also be used to solve the Alavanyo and Nkonya land conflict.

\section{REFERENCES}

1. Aapengnuo, C.M. (2010). Misinterpreting Ethnic Conflicts in Africa. Africa Security Brief, 4.

2. Asabere, P. K. (2004). The pricing of the emergent leasehold (possessory) estates of Ghana. Real Estate Economics. Retrieved from: http://www.accessmylibrary.com/coms2/summary_0286-18335346_ITM [Accessed 30.04.2018].

3. Bates, R.H. (1982). Modernization, Ethnic Competition, and the Rationality of Politics in Contemporary Africa. In: Donald, R., Olunsorola, V.A. (eds.) State versus Ethnic Claims: African Policy Dilemmas. Westview Press, Boulder, pp. 152-171.

4. Boucher, J., Landis, D., Clark, K.A. (1987). Ethnic Conflict: International perspectives. Sage, Newbury Park, CA.

5. Boulding, K. (1963). Conflict and Defense. Harper and Row, New York.

6. Deininger, K., Castagnini, R. (2004). Incidence and Impact of Land Conflict in Uganda. World Bank, Development Economics Group. World Bank Policy Research Working Paper 3248.

7. Deininger, K., Goyal, A., Nagarajan, H. (2010). Inheritance land reform and women' Access to Capital: Evidence from Indian's Hindu succession Act: Pilicy Research working paper 5338. The World Bank Development Research Group/Agriculture and Rural Development Team.

8. Dzathor, P.K. (1999). The Ewe Nation and Sasadu: a brief history. Berkadams, Accra.

9. Food and Agriculture Organisation (2016). No peace without freedom from want. Speech by Graziano da Silva at a side-event on 'Peace and Food Security', hosted by FAO, at the sixth Tokyo International Conference on African Development (TICAD VI, 26-28 August 2016).

10. Francis, M., Tomoyato, M. (2013). Rural-rural Migration and Land Conflicts: Implications on Agricultural Productivity in Uganda. GRIPS Discussion Paper13-17. National Graduate Institute for Policy
Studies7-22-1 Roppongi, Minato-ku, Tokyo, Japan 106-8677.

11. Gariba, J.A. (2015). Land Struggle, Power and the Challenges of Belonging. The Evolution and Dynamics of the Nkonya-Alavanyo Land Dispute in Ghana.

12. Gyasi, E.A. (1994). The adaptability of African communal land tenure to economic opportunity the example of land acquisition for oil palm farming in Ghana. Africa, 64 (3), pp. 391-405. Retrieved from: http:// www.jstor.org/stable/pdfplus/1160788.pdf [Accessed 20.05.2018].

13. HIIK (ed.) (2005). Conflict barometer 2005. Crisis, wars, coups d'état, negotiations, mediations, peace settlements. Retrieved from: http://www.rzuser.uniheidelberg.de/ lscheith/CoBa05.pdf [Accessed 20.05.2018].

14. Imbusch, P. (1999). The Concept of Violence. International Handbook of Violence Research pp 13-39.

15. Kairaba, A. (2002). Rwanda county case study. Paper prepared for "integrating land issues into policy reduction strategies and broader development agenda: A regional workshop on land issues in Africa and middle East Kampala Uganda. Land Net Rwanda/World Bank.

16. Kumado, K., Gyandoh, S.O. (2009). Gyandoh and Griffiths' sourcebook of the constitutional law of Ghana. $2^{\text {nd }}$ ed. Black Mask, Accra.

17. Lasterria-Cornhiel, S., Garcia-Frais, Z. (2009). Gender and Land Rights: Findings and Lessons From Country Studies. FAO Corporate Document Repository.

18. Niklas, L.P., Mikael, S. (2005). Conflict, Conflict Prevention and Conflict Management and beyond: a conceptual exploration. Concept Paper, Central Asia Caucasus Institute \& Silk Road Studies Program, Washington, DC.

19. Nkonya Traditional Council (2013). Press Release on the Nkonya Alavanyo Conflict, January 3, 2013, written and signed by Nana Okotor Kofi III.

20. Nukunya G.K. (2003). Tradition and Change in Ghana. An Introduction to Sociology. Ghana University Press, Accra.

21. Ohene, F. (2013). The fact of the case between Nkonya and Alavanyo. Modern Ghana. Retrieved from: http:// www.modernghana.com/news/454229/1/the-facts-ofthecase-between-nkonya-and-alavanyo.html [Accessed 30.05.2018].

22. Peters, E.P. (2004). Inequality and Social Conflict Over Land in Africa. Journal of Agrarian Change, 4 (3), pp. 269-314.

23. Quarcoopome, S.S. (1992). Urbanisation, Land Alienation and Politics in Accra. Institute of African Studies Research Review, 8 (1-2). 
Proceedings of the 2018 International Scientific Conference 'Economic Sciences for Agribusiness and Rural Economy' No 1, Warsaw, 7-8 June 2018, pp. 182-187

24. Salih, S.A. (1995). Food security in Africa: Concepts, measurement, policy and reality. UNU/WIDER.

25. Sarpong, P. (1974). Ghana in Retrospect: Some Aspects of Ghanaian Culture. Ghana Publishing Company, Accra-Tema.

26. Vandana, S. (2010). Staying Alive: Women, Ecology and Development. Massachusetts South End Press, New York-Boston.
27. Wehrmann, B. (2005). Urban and Peri-urban Land Conflicts in Developing Countries. Research Reports on Urban and Regional Geography. 2. Berlin.

28. World Bank Group (2008). World Development Report. Agriculture for Development. Washington, DC. 